Covered in: Web of Science (WOS); EBSCO; ERIH+; Google Scholar; Index Copernicus; Ideas RePeC; Econpapers; Socionet; CEEOL; Ulrich ProQuest; Cabell, Journalseek; Scipio; Philpapers; SHERPA/RoMEO repositories; KVK;

WorldCat; CrossRef; CrossCheck

2022, Volume 14, Issue 1, pages: 69-92 | https://doi.org/10.18662//rrem/14.1/508

\section{Activation of Students' Cognitive Activity in the Context of Filling Educational Components with Health Preserving Content. Forming a Health Preserving Competence}

\author{
Tetiana KOCHUBEI', \\ Nelia KRAVCHUK², \\ Olha MELNYKOVA ${ }^{3}$
}

\begin{abstract}
${ }^{1}$ Doctor of Pedagogical Sciences, Professor, Professor of the Department of Social Education and Social Work of Pavlo Tychyna Uman State Pedagogical University, Ukraine, udpu tania@ukr.net ${ }^{2}$ Candidate of Pedagogical Sciences, Assistant Professor of the Department of Psychology and Pedagogics of Child Development of Pavlo Tychyna Uman State Pedagogical University, Ukraine, nelli-kravchuk@,ukr.net

${ }^{3}$ Candidate of Pedagogical Sciences, Assistant Professor, Assistant Professor of the Department of Psychology and Pedagogics of Child Development of Pavlo Tychyna Uman State Pedagogical University, Ukraine, olga@maistruk.com
\end{abstract}

Abstract: A content analysis of the process of obtaining education by students, which shows that the traditional approach is ineffective in terms of forming their health preserving competence has been carried out.

Therefore, the purpose of the study is to develop, scientifically substantiate and experimentally test the effectiveness of the methodology for forming a health preserving competence by activating students' cognitive activity in the context of filling educational components with health preserving content.

In the course of the study, the empirical methods such as pedagogical observation, interviews, surveys, questionnaires, a project method, tests, and mathematical statistics methods have been used.

The methodology for forming a health preserving competence in future teachers in the process of professional training has been developed, tested and put into practice, which has ensured the optimization of this process.

The proposed by the authors and experimentally tested pedagogical condition.

The obtained findings have proved the originality, effectiveness of implementing the developed methodology in the practice of higher education institutions, as well as the practical feasibility and efficiency of the proposed step-by-step methodology. The evidence of this is that the high level has increased by $10 \%$ of EG students and by $0.8 \%$ of CG students with a difference of $<9.2 \%$. Accordingly, the sufficient level has increased by $12 \%$ in EG students and by $3.1 \%$ in CG students with a difference of $<8.9 \%$. The average level has decreased by $7.0 \%$ in EG students and by $1 \%$ in CG students with a difference of $<6 \%$. Finally, the low level has decreased by $87 \%$ in EG students and by $28 \%$ CG, which indicates the effectiveness of the proposed pedagogical condition.

Keywords: health preserving competence, methodology for forming a health preserving competence, future teachers, higher education institutions, preschool education institutions.

How to cite: Kochubei, T., Kravchuk, N., \& Melnykova, O. (2022). Activation of Students' Cognitive Activity in the Context of Filling Educational Components with Health Preserving Content. Forming a Health Preserving Competence. Revista Romaneasca pentru Educatie Multidimensionala, 14(1), 69-92.

https://doi.org/10.18662/rrem/14.1/508 


\section{Introduction}

Under modern conditions of the crisis and increasing competition in various spheres of life, health becomes especially important. Therefore, in our opinion, the interest in the modern youth values is determined by the role it plays in the process of social renewal and development, where health is a resource for qualitative transformation. In addition, general civilizational trends towards humanization, protection of human rights and freedoms, quality of life and social well-being actualize health issues not only at the state level, but also in the life strategies of individuals. The topicality of the study is also determined by the level and quality of the health status of the younger generation. Both in Ukraine (Andriushchenko, 2015; Anohina, 2007; Bobrytska, 2010; Kravchuk \& Kochubei, 2016 etc.) and abroad (Olsen \& Nesbitt, 2010; Pirzadeh et al., 2012; Webster, 2014 etc.) a healthy lifestyle becomes a priority as a security factor for every state in the process of strengthening and preserving the health of younger generations.

Therefore, the problem of improving the effectiveness of a person's education becomes relevant, the solution of which depends on forming professional competence of an educator as the main figure of education, in particular future teachers of preschool education institutions.

The main task of higher education institutions is to prepare them for professional activity, taking into account the problems of modernization of the Ukrainian education system, to form a competent, responsible, competitive and highly cultured educator, ready for further professional growth, social and professional mobility (Fizeshi, 2020). This highlighted the importance of forming a health preserving competence, which complements the list of professional qualities of a modern educator with readiness to ensure the protection of children's life and health. Therefore, there is an obvious need to intensify the cognitive activity of students of higher education institutions in the context of filling the educational components with health preserving content and to prepare them for professional activity in preschool education institutions.

The scientific background for the development of theoretical foundations for forming a health preserving competence of future teachers of preschool education includes: health preserving competencies, formation of healthy lifestyle skills, health culture of students of higher education institutions (Andriushchenko, 2015; Al-Amari, 2015; Gaisina et al, 2019; Martseniuk \& Shtykh, 2015; Shovkoplias, 2016). We agree with the scholars 
that an educator is a model of a healthy lifestyle and the attitude of the younger generation to their own health depends on him/her.

In a broad sense, forming a health preserving competence of future teachers of preschool education institutions is presented in the works of Shovkoplias (2016), Andriushchenko (2015), Kravchuk \& Kochubei (2016).

The significant contribution to the study of the problem was made by such scholars as Al-Amari (2015), Anohina (2007), Assaf et al. (2019), Brett (2011, 2012), Gaisina et al. (2019), Hanawi et al. (2020), Hej (1996), Hohel' \& Hohel' (2016), Kazachiner \& 'Tkachenko (2020), Nishi (2009), Salem (2008), Toman (1988), Uajt (1990), Webster (2014) and others.

The analysis of their works allowed us to develop a new scientific context of the problem of forming a health preserving competence, namely, the activation of students' cognitive activity in the context of filling educational components with health preserving content.

In the study of Kazachiner and Tkachenko (2020) a health preserving competence is defined as a high personal level of perfection of health preserving activity, which is characterized by deep knowledge about preserving and strengthening health, fluent usage of medical rescue measures and possession of relevant competences.

Anohina (2007) considers forming a health preserving competence as a readiness to independently solve tasks related to the maintenance, strengthening and preservation of the health of both one's own and the others.

We agree with Anohina (2007) and Kazachiner and Tkachenko (2020), that a health preserving competence is a process of acquiring the knowledge about health preservation, the experience of self-preservation, the means of health improving methods and health preserving technologies, and the ability to organize health preserving activities.

According to Bielienka (2015), future teachers of preschool education institutions are responsible for preserving, strengthening and recovering the health of preschoolers. It is they who should set a personal example of health preservation for preschool children. Therefore, in the process of studying in higher education institutions, they should develop a high level of knowledge, skills and experience that are necessary for successful professional activity.

After analyzing the studies (Bielienka, 2015) on the problems of preparing students for professional activity, we came to the conclusion that they have not developed specific recommendations for forming students' health preserving competence and readiness for health preserving activities in preschool education institutions. Therefore, the problem of forming 
students' skills not only to take care of their own health and the health of others, but also to have the knowledge about the means of preserving it and about health preserving technologies, as well as to skillfully implement them in the educational process of preschool institutions, is of particular importance.

After all, the experience of health preservation is gradually accumulated in practice, polished by the introduction of the latest modern technologies. This approach in the process of professional training will encourage students to use the acquired knowledge in practice and will contribute to preparing for active health preserving activities. Therefore, in the study, we focused on such a pedagogical condition as activation of cognitive activity of students of higher educational institutions (hereinafter referred to as HEI) in the context of filling educational components with health preserving content.

This condition reflects the specifics of the educational process in order to take into account the individual abilities, needs, interests of future teachers and provides an optimal combination of methods, means, techniques and technologies of teaching, as well as a combination of the knowledge and experience of health preservation. By "health preserving activities" we mean human activities aimed at forming, maintaining and strengthening the health of both one's own and other people, forming health culture, health ecology, holistic formula for a healthy lifestyle, as well as the ability to make changes in the environment and lifestyle, using and combining optimal methods of teaching and upbringing, and the ability to predict the expected results.

The content analysis of students' learning activities shows that the traditional approach is not effective enough in forming students' health preserving competence. There are some contradictions between: the society's requirements for a health preserving competence of future specialists and insufficient scientific and theoretical development of the problem of forming a health preserving competence of future teachers of preschool education institutions in the process of professional training; the need to update the content, forms, methods, means, technologies for forming a health preserving competence of future teachers of preschool education institutions and the lack of reasonable pedagogical conditions for their implementation.

Consequently, the implementation of the outlined pedagogical condition will contribute to improving high and sufficient levels of forming a health preserving competence. 
To this end, we have identified the main directions of forming a health preserving competence of future teachers of preschool education institutions (hereinafter referred to as PEI): educational, health preserving, psychological-pedagogical, preventive and reflexive.

\section{Purpose of the study}

The purpose of the article is to develop, scientifically substantiate and experimentally test the effectiveness of the introduction of the pedagogical condition - activation of students' cognitive activity in the context of filling educational components with health preserving content during forming a health preserving competence of future teachers of PEI in the process of professional training.

\section{Study methodology}

According to the purpose of the study, the following methods have been used: theoretical - analysis, synthesis, comparison and generalization of scientific sources on the study problem, which made it possible to determine the purpose of the study, to clarify the essence of the key concepts; empiricalinterview, pedagogical observation, survey, questionnaire, testing, a project method - in order to determine the level of formation of a health preserving competence of future teachers of PEI; pedagogical experiment (ascertaining, formative) - to determine the effectiveness of the implementation of the selected pedagogical condition for forming a health preserving competence of future teachers of PEI in the process of professional training; statistical: methods of mathematical statistics for the quantitative and qualitative analysis of the experimental data and determining the reliability of the results.

The methodological basis of the research consisted of the following approaches: activity-based, personality-oriented, health-preserving, competence-based.

\section{Study design}

The authors of the article have developed a program of experimental work to determine the levels of a health preserving competence in future teachers and track the dynamics of the development of the studied phenomenon. The ascertaining experiment was aimed at determining the levels of formation of college students' health preserving competence based on the criteria, levels and indicators defined in its structure. 
The ascertaining phase of the experiment was preceded by a pilot study (questionnaires, interviews, observations and surveys), during which it turned out that although the problem of health preservation is generally accepted and given considerable attention in the HEI, and although the students have knowledge of health preservation, but they rarely use it in practice. We have found that it is not typical of the students to lead a healthy life, take care of all components of health and gain the experience of systematic recovery. This indicates that the students have a low level of a health preserving competence, which can be increased through proper work with them, namely: regular physical exercises; the compliance with the relevant pedagogical condition, the use of health improving and health preserving technologies, the enhancement of the respondents' motivation to lead a healthy life, the involvement in organizing health preserving activities in PEI.

The ascertaining experiment was conducted to determine the initial level of a health preserving competence in future teachers. 472 students from Vinnytsia Humanitarian Pedagogical College, Taras Shevchenko Uman Humanitarian Pedagogical College, Borys Grinchenko Kiev University College and Odesa Pedagogical College took part in the experiment. 243 students participated in the experimental group (hereinafter referred to as EG), and 229 students participated in the control group (hereinafter referred to as CG). The difference between the selected groups was that in the EG the pedagogical condition developed by us was implemented, and in the CG the study of professional disciplines was carried out according to the traditional curriculum.

The study was conducted in two stages: I - analytical and modeling; II - experimental and generalizing.

In the course of the study, the following methods were used: questionnaire survey, test methods, conversations, interviews, observation of professional activities in practice. To determine the level of formation of students' health preserving competence, diagnostic methods, questionnaires and tests were used (self-esteem test, stress tolerance test, self-test by J. Rotter) (Tytarenko, 2009). Based on the results, the percentage of the respondents' positive ratings for each criterion was determined.

The results of the ascertaining experiment allowed us to distinguish four levels (high, sufficient, medium and low) of the studied phenomenon and showed that the majority of the respondents are at low and medium levels of the health preserving competence formation. We believe that the reasons for this are: (1) the students at the low level have knowledge about the essence of a health preserving competence; 
(2) academic disciplines do not provide the study of topics related to their own health preservation and mastering the methods of health strengthening; (3) there is no purposeful psychological and pedagogical influence on gaining the experience in leading a healthy life, in self-regulation and selfcorrection; (4) the means, forms and methods of health preservation are not used for their own health improvement; (5) the methodology for forming a health preserving competence in future teachers of PEI, the introduction of which would ensure their readiness for health preserving activity has not been developed

It caused the necessity to develop the methodology of the study.

The formative stage of the study covered 4 years (2016-2020). The experiment was conducted at Vinnytsia Humanitarian Pedagogical College, Taras Shevchenko Uman Humanitarian Pedagogical College, Borys Grinchenko Kiev University College and Odesa Pedagogical College. The experimental (243 students) and control (229 students) groups were formed in every HEI. The total number of participants was 472 students. All participants were informed about the aims and objectives of the experiment. They were also informed that their participation in the experiment was voluntary and they had the right to refuse it at any time.

After the formative experiment, the data of the CG and EG were evaluated and compared. To check the reliability and statistical validity of the significant changes in the levels of students' health preserving competence (HPC) development, mathematical statistics methods and the Microsoft Excel table processor with its built-in statistical functions were used. The levels of the formation of a health preserving competence of future teachers of PEI in general and according to various criteria and indicators were evaluated according to a four-point system: low level - 1 point, medium level - 2 points, sufficient level - 3 points, high level - 4 points.

Student's t-test was used to determine the difference between the mean values of the levels of each of the indicators in the experimental and control groups. To test the reliability and statistical validity of the significant changes in the levels in the experimental and control groups, we used Pearson's chi-squared test ( $\chi^{2}$ criterion).

Based on the substantiation of the theoretical basis, we have identified the pedagogical condition - the activation of students' cognitive activity by filling the educational components with health preserving content, which was implemented at all stages of the experimental work and provided the optimal combination of the following methods, means, methods and teaching technologies: students' independent research activity (presentations, student scientific conferences, trainings, pedagogical 
practice). The main means were the compliance to hygiene routines, the use of healing powers of nature, the means of overcoming emotional stress, physical exercise.

At the analytical and modeling stage of the experimental work, the authors conducted interviews with the teachers, discussed the results and informed them about the implementation of a reasonable pedagogical condition, and provided methodological materials on the formation of a health preserving competence of students of HEI. The analysis of the results of this stage was based on the observations of teachers and interviews with the students of the experimental groups, during which the studied pedagogical condition was realized.

At the experimental and generalizing stage of the study, the aim was to form the readiness of future teachers to health preserving activities in PEI.

The educational direction included the creation of comfortable learning conditions in higher education institutions, which contributed to the integration of educational and health preserving activities, a systematic approach to preserving and strengthening students' health. The work in this direction was carried out in the form of competitions, health days, periodic medical and preventive health improving measures, creating a situation of positive interdependence of health and learning, when educational activities contribute to improving the health of students. After all, the important components of the future preschool teachers training process are the acquisition of special knowledge and skills that ensure their readiness to lead health preserving activities.

In order to form a health preserving competence of future teachers of PEI, the content of the disciplines of natural-and-scientific training and the discipline of professional-and-practical training was adjusted. The course "Formation of a Health Preserving Competence of Future Teachers in the Process of Professional Training" introduced by the authors of the article and the course "Physical Education" became supplementary.

The students gradually assimilated the content, forms, methods and means of forming a health preserving competence with the help of the lecturers who selected and used various teaching methods, techniques and technologies that met the educational and cognitive capabilities of the students. In particular, a number of objectives were accomplished:

- in order to form a health preserving competence of students integrated blocks were introduced in lecture courses: "Methods of Physical Education", "Anatomy, Physiology and Hygiene of Preschool Children", "Fundamentals of Medical Knowledge", "Fundamentals of Pedagogical 
Skills". Thus, the questions about individual physical development of a human body; definition of the concept of "health", its signs and indicators; components of health; taking care of one's own health were additionally included in the lecture in "Anatomy, Physiology and Hygiene of Preschool Children" on the topic "Growth and Development of the Child's Body";

- interactive learning technologies (problem questions, group work, business games, etc.) were used during lectures, which helped to increase the efficiency of mastering the system of necessary knowledge by future teachers, forming professional skills and abilities, students' independent and individual creative work, the use of interactive learning technologies;

- practical classes were conducted with the use of interactive and health preserving teaching methods to consolidate theoretical knowledge, to form skills and abilities of modeling health preserving technologies and to determine the practicability of their use depending on the pedagogical situation;

- encouragement for independent physical exercising was provided. Creating an individual health improving system, every student of the experimental group had the opportunity to choose the optimal type of exercise (Pilates, fitball, stretching, breathing exercises, autogenic training, self-massage, aerobics, step aerobics, etc.);

- meetings and trainings with people who lead a healthy life were organized. These meetings covered the following topics: "Giving up Bad Habits", "Healthy Food, Nutrition", "Active Recreation and Training", "Environment", "Personal Hygiene", "Positive Emotions", "Psychological Guidelines on a Long Healthy Life", "Healthy Lifestyle of a Person", "Physical Education and Sports in Your Life", "Stress and Life Satisfaction", etc.;

- to determine the level of self-esteem and the level of stress resistance Holmes and Rahe tests were performed (Rajgorodskij, 1998);

- methods of control and assessment of students' academic achievements, checking the degree of assimilation of the elements of knowledge, skills and abilities on certain topics were used. The students performed a number of tasks of exploratory and creative nature (work with the textbook, preparation of reports, summaries, development, conducting and analysis of health preserving technologies, annotating articles on health preservation, mutual evaluation of group mates, work with schemes, educational dialogues, discussions, round tables, business games, etc.);

- individual and independent work of the students as an integral part of preparation for classes was carried out; 
- the content of the authors' course "Formation of a Health Preserving Competence of Future Teachers in the Process of Professional Training" was developed;

- the most accessible methods of hardening were used in order to boost the immune system (contrast shower, pouring cold water on certain parts of the body, gargling with herbal decoctions, walking barefoot, etc.);

- the content of the disciplines "Introduction to the Speciality", "Anatomy, Physiology and Hygiene of Preschool Children", "Methods of Physical Education", etc. was improved with the additional inclusion in the lecture courses health preservation issues;

- the following forms of activity were carried out: students' independent research activity, pedagogical practice, scientific student conferences, trainings, round tables, watching of video materials, seminars, methodical digests, kaleidoscopes of pedagogical discoveries, presentations;

- the following teaching methods were used: problem situations, interactive learning technologies, watching of video materials, creating health preserving projects, deductive and inductive methods.

- means of training: sports competitions, sections, clubs, tourism, independent organization of leisure, compliance with the daily routine, rational nutrition, work and recreation, public and personal hygiene, hygiene of learning, etc.

The project method (research, adventure, games, information, practical and organizational) was used in the experimental study to help the students to understand peculiarities of the content and nature of the project. The introduction of this method was intended to teach students to determine a specific program of actions and guidelines (collection of information, processing, finalizing the results and their presentation).

The health preserving direction included students' awareness of the importance of gaining knowledge, skills and experience of their own health preservation, knowledge of anatomical-physiological and psychological-pedagogical features and the reasons of a child's behavior in order to preserve, strengthen and restore preschool children's health, which will help a future teacher to correctly influence the health preserving behavior of preschoolers.

It is extremely important for the health improvement of every nation that future teachers of PEI realize themselves as a part of the health preserving chain as a necessary condition for their forming a holistic picture of children's health preservation and health preserving competence. At the same time, a student must realize the inner spiritual need for their own 
health preservation, understand modern methods, techniques and technologies of health improving.

The implementation of the health preserving direction during the pedagogical practice in the process of professional training of future teachers of PEI included active partnership between teachers and students, common guidelines for achieving a unified goal, which depends on a well-coordinated system of actions of all participants in the educational process and an active health preserving position of future teachers as equal participants in this process in the circle of other participants, in an atmosphere of mutual assistance, security, openness, trust, mutual respect.

It should be noted that forming a health preserving competence of future teachers of PEI naturally arises in the process of subject-subject interaction and cognition at the level of an academic discipline content filled with health preserving technologies, the use of health preserving methods, students' solving vital tasks, associated with the integrity of the worldview, health preserving consciousness.

At the same time, it is important to be able to develop selfconfidence, inner peace, harmony with the world around you and life satisfaction, which is considered the main component of personal wellbeing, as well as a global and conscious assessment of one's own life as a whole (Doktorová et al., 2020). In our opinion, the best methods in this aspect are the methods of intellectual and psychological influence.

At the stage of situation modeling, the modeling method proved to be effective for developing the ability of students to accumulate knowledge about methods and techniques of health preservation, as well as to form the ability to compile a summary of selected technologies and model them. This method was used during practical classes.

In order to ensure the psychological comfort of the individual and implement the psychological and pedagogical direction, we used methods of intellectual and psychological influence:

- mental and spiritual healing (Hohel' \& Hohel', 2016) "Levels of Consciousness", for the students to understand their strong and weak points, solve problems depending on their own level of consciousness, which will ensure personal development and growth);

- spiritual and physical healing (Hej, 1996) "You Can Heal Your Life, Heal Your Body. The Power is Within You" in order to love ourselves, to overcome anger and criticism of others, feelings of guilt and fear, to make positive changes in life (self-approval and self-acceptance, joy of the very process of life); 
- organizing one's own life (Brett, 2012, 2011) "Be the Miracle: 50 Lessons for Making the Impossible Possible" in order to learn to think positively, to act here and now, to change yourself and the world for the better, to multiply good and overcome obstacles in your path without harming your health, and to find your own, right path. And also her work "God Never Blinks: 50 Lessons for Life's Little Detours" in order to perceive your life as a gift, to believe in miracles, to overcome negative emotions of envy, jealousy, etc., to learn to give in and not to take offense, continue to work on self-improvement;

- healing, rejuvenating affirmations by Sytin (2010) with the aim of figurative and volitional adjustment to rejuvenation, longevity and health, which allowed to adjust students to positive thinking and harmony with themselves;

\section{Games";}

- methods of nonverbal communication (Salem, 2008) "Mind

- methods of determining self-states (Berne, 1996) "Games People Play". The purpose is to determine the self-states, a holistic system of sensations and a set of patterns of behavior, understanding that people can shift from one state to another);

- methods of self-improvement (Toman, 1988) "How to Improve Yourself" in order to analyze their actions and deeds, character, their own health, treatment of people, attitudes to life, education and self-education, interests and hobbies, self-knowledge, success and planning of own development;

- methods of communication with people (Dinoil, 1993) "The Course of Development of the Hidden Spiritual Forces of Man. Physical and Moral Revival";

- methods of owning one's own thoughts (Zhikarencev, 2010) "The Path to Freedom. How to Change Your Life" in order to improve health, harmonize relationships with people, achieve prosperity and wellbeing;

- methods of "easy life" (Mangan, 1998) "The Secret of Perfect Life" in order to get rid of one's own fears, to fight depression and despair, to know oneself, to set goals and achieve them, to achieve success, to get rid of bad habits, to fight illness and to preserve health, to be always a happy person and not to succumb to the blows of fate;

- the secrets of a happy family life (Uajt, 1990) "Family and Health";

- meditations on happiness (Ben-Shahar, 2007) "Being happier. Today. Now. Always"; 
- visualizations to relieve emotional stress (Webster, 2014) "Aura. How to Clean, Strengthen and Protect";

- secrets of longevity by A. Voron "Many Years. Good Years. Commandments of 104-year-old Andriy Voron - How to Live Long in Happiness and Joy" (Dochynets, 2012).

For example, using the methods of the psychologists Stanislav and Elena Hohel' (2016), we determined the levels of consciousness of every student. To this end, students worked on shortcomings at each level. They constantly increased their level of consciousness, the ability to determine the movement to their own freedom and increase the life territory, personal growth, self-improvement, the path to life satisfaction, evaluated changes in the perception of the world and responsibility for their own health and happiness, their understanding of strengths and weaknesses, the ability to solve problems to ensure personal development.

The use of affirmations by Hej (1996) helped to direct the students' attention to health problems and the probable cause of illnesses. The introduction of these methods encouraged the students to learn to love themselves and respect their personality: to feel love for the very process of life; to rejoice at the fact that we live and see the beauty; to love other people, own body, animals, birds and all living things, the universe and the way it is arranged. Adjust the students to believe that the key to positive changes in our lives is to never, under any circumstances, criticize ourselves. There are ten ways to cultivate self-love: (1) to abandon self-criticism; (2) stop scaring yourself with gloomy thoughts; (3) be gentle, patient, kind to yourself; (4) learn to be kind to our mind; (5) learn to approve of yourself; (6) to love oneself; (7) love your troubles and shortcomings; (8) take care of your own body; (9) work with a mirror; (10) love yourself now.

During the experimental work we also used:

- health-improving tales (Semina, 2016) Elfika's tales "Life as a Miracle. A Journey with a Magic Feather"; the ability to identify a life problem and find ways to overcome it with the help of fairy tales;

- health-improving technologies - autogenic training and psychogymnastics, games and exercises for the development of the emotional sphere, training games to remove negative emotions and a neurotic state, healing mudras, soul etudes, mood screen, days of mental balance, meditation games, etc.

While forming the students' positive "self-concept" as a holistic, though having some internal contradictions, the image of their own "self", which is a person's attitude towards himself/herself, the following 
components were emphasized: (1) cognitive; (2) evaluative; (3) behavioral (Prykhodko \& Yurchenko, 2012).

At this stage, the experimental work was aimed at giving the students the opportunity to understand the peculiarities of using the methods of psychological self-regulation, as well as using techniques regulating their own psychological state and other people' states. This stage introduced the students to the methods of determining the psychological state of a person, the conscious analysis of one's own actions, character, health, the treatment of other people, the attitude to life, education and selfeducation, interests and hobbies in order to realize one's own self, to achieve success and to plan own development; personal growth, self-improvement, the path to life satisfaction, changes in one's perception of the world and responsibility for one's own health and happiness, etc. As well as the development of the ability to give recommendations for improving mental state through the use of the studied methods and techniques.

Psychodiagnostic methods were used to determine the state of the students' self-concept formation: the study of different images of "selfconcept", Self-concept test questionnaire and "Professional self-concept".

In order to implement the preventive direction, the authors' course "Forming of a Health Saving Competence in Future Teachers of Preschool Education Institutions in the Process of Professional Training" was developed and used in class, which harmoniously combined theoretical and practical training of future teachers and the acquisition, formation and consolidation of the knowledge, skills and the experience of health preserving.

The main goal of the authors' course was to enrich students with knowledge about the content, theoretical foundations and conditions for acquiring a health preserving competence in the process of professional training; forming their positive motivation to preserve, strengthen and recover both their own health and the health of the others, selfimprovement, targets and self-actualization while forming a health preserving competence.

The value of the authors' course was proved by the fact that according to the syllabus the students were expected to assimilate knowledge, to form skills, to gain experience in the topics and the use of methods of monitoring and evaluating students' achievements, to complete tasks of exploratory and creative nature, including: work with the textbook, preparation of summaries, abstracts, reports and reviews, creation of projects, annotating articles on health preservation, conversations, round tables, educational discussions. There were defined the main forms and 
methods: students' independent research activity, presentations, trainings, pedagogical practice; student scientific conferences.

The authors' course helped to form the future teachers' motivation for health preservation, the desire to lead a healthy life, develop creative abilities, encouraged initiative, non-standard thinking, the use of familiar material on the topic, the expansion and deepening of the knowledge provided by the experimental syllabus and had a health preserving orientation. While choosing the forms, methods and techniques of experimental work, interests, age and individual characteristics of the students were taken into account.

In order to experimentally test the pedagogical condition, the content and teaching methods, certain topics of the courses were improved: "Pedagogy with the Fundamentals of Pedagogical Skills" (topics: "Problems of Children' and Adolescents' Health Preservation in Modern Theory and Practice", "Forming a Competent Preschool Specialist in the System of Modern Education"), "Technologies ("Introduction to the Speciality "Preschool Education") (topics: "Professional and Health Preserving Competence of a Future Teacher of PEI", "Health Preserving Competencies of Students of Higher Education Institutions"), "Anatomy, Physiology and Hygiene of Preschool Children" (topics: "Forms, Methods, Means and Technologies of Human Health Improvement", "Assessment of Health State, Physical Development and Physical Fitness of Children and Adolescents"), "Methods of Physical Education" (topics: "Traditional and Non-Traditional Health Improving and Health Preserving Technologies in the Education System", "Fundamentals of Psychophysical Development of a Personality"), "Fundamentals of Medical Knowledge" (topics: "The Problem of Health in the Modern Society", "Fundamentals of a Healthy Lifestyle. Hygienic Conditions Regulating the Youth Labour Protection"). During practical classes in these disciplines autogenic trainings, physical activity breaks, self-massages, psycho-gymnastics, health improving affirmations were organized; innovative technologies were used during binary classes, situation modeling classes, seminars-discussions, debates, role-playing games; health preserving projects were created; methodical guidelines on students' pedagogical practice concerning health preservation of children were developed; independent, individual research activity of the students was carried out.

A special role in class and during independent activity had the creation of a students' positive attitude to a healthy lifestyle and their own health preservation through the following forms of activity: creative works on topical issues in modern science; watching videos demonstrating the 
benefits of a healthy lifestyle; the analysis of lives and activity of long-livers; the study of the Ukrainian Cossack pedagogy, the purpose of which is the spiritual development of a future defender of the native land, national selfconsciousness, physical perfection of the Cossacks; presentations of the highest achievements in the field of health preservation, creation of the "The Book of Health", etc.

The following forms of the upbringing activity in HEI proved to be valuable: contests, hikes, competitions, evenings, exhibitions, festivals, sports holidays and entertainment, health days, etc. The improvement of the effectiveness of such activity depends on many factors: the educational process conditions, the students' motivation for a healthy lifestyle, relations between teachers and students and the effectiveness of the HEI system.

During our experimental study, we assumed that a health preserving competence also depends on an individual's life experience and the desire to change one's life for the better and to improve one's health.

In particular, as part of the experiment the students visited a series of trainings: health preserving motivation "I want to be healthy! I will be healthy!", health preserving behavior "The lifestyle I choose"; health preserving competence "I will live a long, happy life and teach it to others".

During the study, we organized a series of seminars for the students aimed at mastering health preserving methods and techniques (for example, "Positive Thoughts", "Autogenic Training and Psycho-Gymnastics", "Benefits of Neurobics", etc.) in order to form the basic values of health preservation, awareness of their own way of life, choice of ways and methods of improving health preserving skills, ability to reflect and responsibility for their own health preservation as the highest value.

The implementation of the reflexive direction was carried out using the method of reflection. Thus, during the practical activity, students analyzed their own health preserving activity, watched the video of the work that had been completed, determined the attitude of other participants to their activity.

To carry out personal reflection, the students were helped to understand themselves and to achieve success in various aspects of life. For this purpose, the method of self-knowledge by Ivashchuk \& Onyshkevych (2010) was used. The students were asked to keep a diary noting events, facts, feelings and to study the guidelines on self-knowledge: Step 1 - selfobservation (this is an observation, the object of which is the mental state and actions of the subject); Step 2 - self-criticism (the ability to see themselves as if from the side, objectively assess their abilities and capabilities, notice, criticize, correct every negative action) (although, taking 
into consideration the method by Hej (1996), it was recommended to selfcriticize themselves in exceptional cases); Step 3 - self-analysis (awareness, introspection and analysis of their actions and deeds); Step 4 - self-esteem (an important element of self-knowledge, the ability to assess themselves, their place in life and among other people, their abilities, capabilities, inclinations). This technique allowed the students to evaluate themselves, their own behavior, let them live in harmony with themselves and, as a result, to preserve their own health and the health of the others.

Object-functional reflection was expressed through a comprehensive diagnosis of a health preserving competence of future teachers, as it was aimed at studying the following aspects: students' attitude to their own health, their motivational readiness to carry out health preserving activities, ability to apply health preserving technologies, reflection on their own health preserving activities, etc.

Interpersonal reflection was expressed through awareness of their interactions with other subjects of the educational process (teaching staff, children and parents). The students were involved in the process of creating a health preserving educational environment, where they reasonably expressed their health preserving position, independently found the means to lead a healthy life, created an individual health improving program and acquired the necessary skills and abilities of health preserving behavior.

The situation of success was created during students' activities, which allowed all the participants to feel the significance of their own discoveries and satisfaction with the learning process.

In order to develop the students' ability to reflect on their own professional activities, the seminar "Professional Reflection of a Future Teacher of a Preschool Education Institution" and the round table "Forecasting the Development of a Health Preserving Process in the Educational Environment of PEI" were held in the colleges. The participation of the students in the seminars, round tables, scientific student conferences gave them the opportunity to learn more about various aspects of forming their own health preserving competence.

\section{Results of the study}

At the experimental and generalizing stage, the study focused on understanding the process of forming a health preserving competence, forming a stable motivation for health preservation, improving knowledge, skills and abilities of a healthy lifestyle, establishing health preserving consciousness, developing interest in daily physical exercise, gaining 
Activation of Students' Cognitive Activity in the Context of Filling Educational ... Tetiana KOCHUBEI, et al.

experience in preserving, strengthening and restoring one's own health and the health of surrounding people on the basis of readiness for health preserving activity and creation of the individual program of health improvement. The process of students' understanding of a health preserving competence to realize themselves as persons, the ability to independently determine life values, lifestyle and human behavior in accordance with established values, the ability to model health preserving and health improving technologies was monitored.

During the control reviews, the students were provided with comfortable conditions, which allowed an objective assessment of the results of introducing the pedagogical condition under study.

According to our study, we present the results of the levels of a health competence formation of future teachers of PEI at the analytical and modeling (Table 1) and the experimental and generalizing (Table 2) stages of the experiment.

Table 1. Results of the analytical-modeling stage of the experiment

\begin{tabular}{|c|c|c|c|c|c|c|}
\hline \multirow[b]{2}{*}{ Levels } & \multicolumn{3}{|c|}{ Beginning of the experiment } & \multicolumn{3}{|c|}{ End of the experiment } \\
\hline & $\begin{array}{c}\text { Total } \\
\text { (persons) }\end{array}$ & EG & CG & $\begin{array}{c}\text { Total } \\
\text { (persons) }\end{array}$ & $\mathrm{EG}$ & CG \\
\hline High & $16(3.4 \%)$ & $9(1.9 \%)$ & $7(1.5 \%)$ & $48(10.1 \%)$ & $26(5.5 \%)$ & $22(4.6 \%)$ \\
\hline Sufficient & $48(10.2 \%)$ & $23(4.9 \%)$ & $25(5.3 \%)$ & $92(19.5 \%)$ & $52(11 \%)$ & $40(8.5 \%)$ \\
\hline Average & $210(44.5 \%)$ & \begin{tabular}{|l|}
108 \\
$(22.9 \%)$
\end{tabular} & $\begin{array}{l}102 \\
(21.6 \%)\end{array}$ & $187(39.6 \%)$ & \begin{tabular}{|l}
95 \\
$(20.1 \%)$
\end{tabular} & $\begin{array}{l}92 \\
(19.5 \%)\end{array}$ \\
\hline Low & $198(41.9 \%)$ & $\begin{array}{l}95 \\
(20.1 \%)\end{array}$ & $\begin{array}{l}103 \\
(21.8 \%)\end{array}$ & $145(30.7 \%)$ & $\begin{array}{l}65 \\
(13.7 \%) \\
\end{array}$ & $80(17 \%)$ \\
\hline
\end{tabular}

Table 2. Results of the experimental-generalizing stage of the experiment

\begin{tabular}{|c|c|c|c|c|c|c|}
\hline \multirow[b]{2}{*}{ Levels } & \multicolumn{3}{|c|}{ Beginning of the experiment } & \multicolumn{3}{|c|}{ End of the experiment } \\
\hline & $\begin{array}{c}\text { Total } \\
\text { (persons) }\end{array}$ & EG & CG & $\begin{array}{c}\text { Total } \\
\text { (persons) }\end{array}$ & $\mathrm{EG}$ & CG \\
\hline High & $17(3.6 \%)$ & $11(2.3 \%)$ & $6(1.3 \%)$ & $68(14.4 \%)$ & \begin{tabular}{|l|}
3 \\
$(11.2 \%)$
\end{tabular} & $15(3.1 \%)$ \\
\hline Sufficient & $53(11.2 \%)$ & $35(7.4 \%)$ & $18(3.8 \%)$ & $125(26.5 \%)$ & \begin{tabular}{|l}
95 \\
$(20.1 \%)$
\end{tabular} & $30(6.3 \%)$ \\
\hline Average & $212(44.9 \%)$ & \begin{tabular}{|l|}
15 \\
$(24.3 \%)$
\end{tabular} & \begin{tabular}{|l}
97 \\
$(20.5 \%)$
\end{tabular} & $204(43.2 \%)$ & $42(8.9 \%)$ & $\begin{array}{l}162 \\
(34.3 \%)\end{array}$ \\
\hline Low & $190(40.3 \%)$ & \begin{tabular}{|l}
75 \\
$(15.9 \%)$
\end{tabular} & $\begin{array}{l}115 \\
(24.4 \%)\end{array}$ & 75 (40.3\%) & $2(0.42 \%)$ & \begin{tabular}{|l}
73 \\
$(15.5 \%)$
\end{tabular} \\
\hline
\end{tabular}


After completing the formative experiment, the average values in the control (CG) and experimental (EG) groups were finally checked and comparatively analyzed.

Table 3. Dynamics of changes in the analytical-modeling and experimentalgeneralizing stages of the experiment

\begin{tabular}{|c|c|c|c|c|c|c|}
\hline \multirow{2}{*}{ Levels } & \multicolumn{3}{|c|}{$\begin{array}{c}\text { Analytical- } \\
\text { modeling stage }\end{array}$} & \multicolumn{3}{|c|}{$\begin{array}{c}\text { Experimental- } \\
\text { generalizing stage }\end{array}$} \\
\hline & $\begin{array}{c}\text { Total } \\
\text { (persons) }\end{array}$ & $\mathrm{EG}$ & CG & $\begin{array}{c}\text { Total } \\
\text { (persons) }\end{array}$ & $\mathrm{EG}$ & CG \\
\hline High & $\begin{array}{l}+32 \\
(+6.8 \%) \\
\end{array}$ & $\begin{array}{l}+29 \\
(+6.1 \%) \\
\end{array}$ & $\begin{array}{l}+3 \\
(+0.63 \%) \\
\end{array}$ & $\begin{array}{l}+51 \\
(+10.8 \%) \\
\end{array}$ & $\begin{array}{l}+47 \\
(10 \%) \\
\end{array}$ & $+4(0.8 \%)$ \\
\hline Sufficient & $\begin{array}{l}+44 \\
(+9.3 \%) \\
\end{array}$ & $\begin{array}{l}+38 \\
(+8.0 \%)\end{array}$ & $\begin{array}{l}+6 \\
(+1.27 \%)\end{array}$ & $\begin{array}{l}+72 \\
(+15.3 \%) \\
\end{array}$ & $\begin{array}{l}+57 \\
(12.0 \%) \\
\end{array}$ & $\begin{array}{l}+15 \\
(3.1 \%) \\
\end{array}$ \\
\hline Average & $-23(-4.9 \%)$ & \begin{tabular}{|l|}
-20 \\
$4.2 \%)$ \\
\end{tabular} & $-3(-0.7 \%)$ & $-8(1.7 \%)$ & $-7(1.5 \%)$ & $-1(0.2 \%)$ \\
\hline Low & \begin{tabular}{|l}
-53 \\
$11.2 \%$ \\
\end{tabular} & \begin{tabular}{|l|}
-50 \\
$10.6 \%)$
\end{tabular} & $-3(-0.6 \%)$ & $\begin{array}{l}-115 \\
(24.4 \%)\end{array}$ & $\begin{array}{l}-87 \\
(18.5 \%)\end{array}$ & $\begin{array}{l}-28 \\
(5.93 \%)\end{array}$ \\
\hline
\end{tabular}

Thus, the high level increased by $10 \%$ in EG students and by $0.8 \%$ in CG students with a difference of $<9.2 \%$. Accordingly, the sufficient level increased by $12 \%$ in EG students and by $3.1 \%$ in CG students with a difference of $<8.9 \%$. The average level decreased by $7.0 \%$ in EG students and by $1 \%$ in CG students with a difference of $<6 \%$. Finally, low levels decreased by $87 \%$ in EG and by $28 \%$ in CG students.

To determine statistical reliability and establish the difference between the mean values of the levels of a health preserving competence formation of future teachers of preschool education institutions in the control and experimental groups, they were calculated according to the Student's t-test. Pearson's chi-squared test $\left(\chi^{2}\right.$ criterion) was used to check the reliability of the results obtained.

The analysis of the results of the experiment shows positive changes in the implementation of the proposed pedagogical condition, and the students have demonstrated a conscious focus on forming their own health preserving competence.

\section{Discussion}

The authors of the article agree that it is the activation of students' cognitive activity in the context of filling the educational components with 
health preserving content that is the main goal of forming a health preserving competence.

The scientific value of the study lies in the fact that the authors:

- defined and substantiated the pedagogical condition - activation of students' cognitive activity due to filling professional disciplines with health preserving content;

- clarified the criteria (motivational-valuable, cognitive-intellectual, practical-activity) and the levels (high, sufficient average, low); the essence of the key concepts of the study ("health preserving competence", "forming a health preserving competence of future teachers of preschool education institutions in the process of professional training");

- proposed and introduced into practice the forms, methods, and means of forming a health preserving competence of students of pedagogical colleges;

- proved that it is professionally important for students to acquire a health preserving competence, which is an integral part of the professional competence of an educator.

Based on the findings, we have proposed and implemented the ways to improve forming a health preserving competence of future teachers of preschool educational institutions: the use of a competence-based approach in the process of professional training; the implementation of the pedagogical condition under study for forming a health preserving competence in future teachers of preschool educational institutions in pedagogical colleges; the creation of scientific and methodological support for the process of forming a health preserving competence in future teachers of preschool educational institutions; ensuring compliance of the content, forms, methods, means and technologies with the level of professional training; introduction of new forms, methods, means and technologies of health preservation by all participants of the educational process in pedagogical colleges; creation of the situation of success, psychological comfort, problem-based learning, independent solution and modeling of pedagogical situations; creation of necessary material and technical support for the process of forming a health preserving competence; promotion of self-realization and self-development of a student on the basis of internal motivation for a healthy lifestyle.

The practical value of the study lies in the effective validation of the proposed pedagogical condition and the developed methodology for forming a health preserving competence of future teachers in the process of professional training. The findings of the study can be introduced into the 
practice of pedagogical colleges and upgrade training courses for teachers of preschool education institutions.

\section{Conclusions}

The analysis of the results of the theoretical and experimental study confirmed the validity of theoretical and methodological concepts, showed the prospects for the goal of the study and the dynamics of the results of the experimental program.

The experimental study presents the authors' vision of systematization of the knowledge on the problem of forming a health preserving competence of future teachers of PEI. In the course of experimental work, the effectiveness of introducing the pedagogical condition "activation of cognitive activity of students in the context of filling educational components with health preserving content" was checked, in accordance with the proposed stages and directions of the experiment, which provided an optimal combination of forms, methods, tools and technologies of teaching.

Thus, the high level increased by $10 \%$ in EG students and by $0.8 \%$ in CG students with a difference of $<9.2 \%$. Accordingly, the sufficient level increased by $12 \%$ in EG students and by $3.1 \%$ in CG students with a difference of $<8.9 \%$. The average level decreased by $7.0 \%$ in EG students and by $1 \%$ in CG students with a difference of $<6 \%$. Finally, the low level decreased by $87 \%$ in EG and by $28 \%$ in CG students.

The findings of the study confirmed the originality and effectiveness of introducing the proposed methodology into practice and determined its value and practicability.

The study does not cover all the aspects of this problem. We see the prospect of the further study in the theoretical understanding the process of forming students' health culture in HEI, in the organization of health preserving activity in preschool education institutions; in combining health preserving technologies in the educational process of educational institutions.

\section{References}

Al-Amari, H. (2015). The Perception of College Students about a Healthy Lifestyle and its Effect on their Health. Journal of Nutrition and Food Sciences, 5(6), 1-4. http://doi.org/10.4172/2155-9600.1000437

Andriushchenko, T. (2015). Teoretyko-metodychni zasady formuvannia zdoroviazbereabuvalnoi kompetentnostiv ditei doshkilnoho viku (Theoretical and 
Activation of Students' Cognitive Activity in the Context of Filling Educational ... Tetiana KOCHUBEI, et al.

methodological foundations of the formation of health-preserving competence in preschool children). [Doctoral dissertation, Pavlo Tychyna Uman State Pedagogical University]. PDPU. http://dspace.pdpu.edu.ua/bitstream/123456789/214/1/АнАрюшенко T.K.\%20.pdf

Anohina, I. (2007). Priobshbenie doshkol'nikov k zdorovomu obrazu z̧bizni [ntroducing preschoolers to a healthy lifestyle]. UIPK-PRO.

Assaf, I., Brieteh, F., Tfaily, M., El-Baida, M., Kadry, S., \& Balusamy, B. (2019). Students university healthy lifestyle practice: quantitative analysis. Health information science and systems, 7(1), 7. https://doi.org/10.1007/s13755-019$\underline{0068-2}$

Ben-Shahar, T. (2009). Happier: Learn The Secrets to Daily Joyand Lasting Fulfillment. McGraw-Hill Education.

Berne, E. (1996). Games People Play: The Basic Handbook of Transactional Analysis. Ballantine Books.

Bielienka, H. (2015). Pidhotovka maibutnoho vykhovatelia do roboty z ditmy doshkilnoho viku: kompetentnisnyi pidkbid [Preparing a future teacher to work with preschool children]. Sochinskyi.

Bobrytska, V. (2010). Formuvannia zdorovia molodi: aktualizatsiiz svitovoho retrodosvidu v umovakh suchasnoi universytetskoi osvity [Formation of youth health: actualization of world retro experience in the context of modern university education]. FOP Rybalka D. L.

Brett, R. (2011). God never blinks: 50 Lessons for life's little detours. Grand Central Publishing.

Brett, R. (2012). Bethe Miracle: 50 Lessons for Making the Impossible Possible. Grand Central Publishing.

Dinoil, S. (1993). Kurs razvitija skerytyh dushevnyh sil cheloveka. Fiæicheskoe i nravstvennoe vozrozhdenie. [The course of development of hidden spiritual forces of a person. Physical and moral rebirth]. Izdatel'stvo «Presa Ukraïni».

Dochynets, M. (2012). Mnobii lita. Blabii lita. Zapovidi 104-richnoho Andrïa Voronayak zhyty dovbo v shchasti i radosti. [Many years. Good years. Commandments of 104-year-old Andriy Voron - how to live long in happiness and joy]. Karpatska vezha

Doktorová, D., Hubinská, J., \& Masár, M. (2020). Finding the Connection between the Level of Empathy, Life Satisfaction and Their Inter-Sex Differences. Revista Romaneasca Pentru Educatie Multidimensionala, 12(4), 01-15. https://doi.org/10.18662/rrem/12.4/330

Fizeshi, O. (2020). Peculiarities of preparation of masters for teaching pedagogical disciplines in institutions of higher pedagogical education. Revista 
Romaneasca pentru Educatie Multidimensionala, 12(4), 103-117. https://doi.org/10.18662/rrem/12.4/336

Gaisina, L. M., Shaykhislamov, R. B., Shayakhmetova, R. R., Kostyleva, E. G., Goremykina, L. I., \& Gainanova, A. G. (2019). The essence and structural elements of a healthy lifestyle of students. Revista Espasios, 40(21), 10-19. http://www.revistaespacios.com/a19v40n21/a19v40n21p10.pdf

Hanawi, S., Saat, N., Zulkafly, M., Hazlenah, H., Taibukahn, N., Yoganathan, D, Abdul Rahim, N., Mohd Bashid, N. A., Abdul Aziz, F., \& Low, F. (2020). Impact of a Healthy Lifestyle on the Psychological Well-being of University Students. International Journal of Pharmaceutical Research \& Allied Sciences, 9(2), 1-7.

https://ijpras.com/storage/models/article/Ukm0xb9ZMZdnGWBP3lsqu ReaUoGe1DlqiDljvcXHstFi9VdDS45YoyYJKLa2/impact-of-a-healthylifestyle-on-the-psychological-well-being-of-university-students.pdf

Hej, L. (1996). Isceli svoju z̧hizn'. Isceli svoe telo. Sila vnutri nas [Heal your life. Heal your body. The power is within us]. Oniks.

Hohel', S., \& Hohel', E. (2016). Urovni soznanija, ili put' k schast'ju. [Levels of consciousness, or the path to happiness]. ID «Lotos».

Ivashchuk, L., \& Onyshkevych, S. (2010). Valeolohiia [Valeology]. Navchalna knyha - Bohdan.

Kazachiner, O., \& Tkachenko, L. (2020). Find the connection between the level of empathy, life satisfaction and their difference between the sexes. Revista Românească pentru Educație Multidimensională, 12(3), 268-293. https://doi.org/10.18662/rrem/12.4/330

Kravchuk, N., \& Kochubei, T. (2016). Pedahohichni zasoby formuvannia zdoroviazberezhuvalnoi kompetentnosti maibutnikh vykhovateliv doshkilnykh navchalnykh zakladiv [Pedagogical means of forming the health-saving competence of future teachers of preschool educational institutions]. Proceedings of the international conference. Warsaw: Sp. z o.o. «Diamond trading tour» (pp. 27-30). http://xn-e1aajfpcds8ay4h.com.ua/pages/view/1071

Mangan, D. (1998). Zhivite bezproblem: sekret legkoj zhizni [Live without problems: the secret of an easy life]. Post-Shoppin.

Martseniuk, M., \& Shtykh, I. (2015). Zberezhennia i zmitsnennia zdorovia yak sotsialno znachushcha problema suchasnosti [Preserving and promoting health as a socially significant problem of our time]. Psykholoho-pedahobichni problemy silskoi shkoly. Uman, 53. 372-380.

https://library.udpu.edu.ua/zbirnyky-naukovykh-prats-udpu/2187-vipusk$\underline{53}$ 
Activation of Students' Cognitive Activity in the Context of Filling Educational ... Tetiana KOCHUBEI, et al.

Nishi, K. (2009). Sistema zdorov'ja Nishi. Metodika. Uprazhnenija. Meditacija. [The system is healthy for the Niche. The methodology. Exercises. Meditation]. Izdatel'stvo «Vekton».

Olsen, J. M., \& Nesbitt, B. J. (2010). Health coaching to improve healthy lifestyle behaviors: an integrative review. American journal of health promotion: AJHP, 25(1), 1-12. https://doi.org/10.4278/ajhp.090313-LIT-101

Pirzadeh, A., Sharifirad, G., \& Kamran, A. (2012). Healthy lifestyle in teachers. Journal of education and bealth promotion, 1(46), 24-27. https://doi.org/10.4103/2277-9531.104816

Prykhodko, Y., \& Yurchenko, V. (2012). Psykholohichnyi slovnyk-dovidnyk [Psychological dictionary-reference book]. Karavella.

Rajgorodskij, D. (1998). Prakticheskaja psihodiagnostika: metodiki i testy Practical psychodiagnostics: methods and tests]. BAHRAH.

Salem, M. (2008). Kak chitat' cheloveka. [How to read a person]. Klub semejnogo dosuga.

Semina, I. (2016). Zhizn' kak chudo. Puteshestvie s Volshebnym Peryshkom [Life is like a miracle. A journey with a magic plumelet]. Rech'.

Shovkoplias, O. (2016). Formuvannia zdoroviazberezhuvalnoi kompetentnosti maibutnikh vykhovateliv yak faktor tsinnisnoho stavlennia do zdorovia [Formation of health-saving competence of future caregivers as a factor of value attitude to health]. Conference proceedings Perspective innovations in science, education, production and transport'2016 (pp. 1-7). http://www.sworld.com.ua/konfer45/65.pdf

Sytin, G. (2010). Jenciklopedija isceljajushbih omolazhivajushbih nastroev dlja vsej sem'i. [Encyclopedia of healing rejuvenating moods for the whole family]. Ves'.

Tytarenko, T., Kliapets, O., Lazorenko, B., Liepikhova, L. \& Savinov, V. (2009). Metodyky vyvchennia povsiakdennoho stresu i sposobiv rozviazannia kryzovykh zhyttievykh sytuatsii [Methods of studying everyday stress and ways to solve crisis life situations]. K. : Milenium

Toman, I. (1988). Yak udoskonaliuvaty samoho sebe [How to improve yourself]. Politvydav Ukrainy.

Uajt, J. (1990). Sem'ja i zdorov'e. [Family and health]. Pacific Press Publishing Association.

Webster, R. (2014). The Complete book of Auras: Learnto See, Read, Strengthen \& Heal Auras. Llewellyn Publications.

Zhikarencev, V. (2010). Put' k svobode. Karmicheskie prichiny vozniknovenija problem, ili kak izmenit' svoju zhizn' [The path to freedom. Karmic causes of problems, or how to change your life]. Astrel'-SPb. 